\title{
Implication of Business Strategy in Indian Automobile Industry: A Case of Tata Motors
}

\author{
Yashavantha G. Nayak ${ }^{1}$, Robin M. Shinde ${ }^{2} \&$ Praveena $^{3}$ \\ ${ }^{1}$ Research Scholar, College of Management and Commerce, Srinivas University, Mangalore, \\ India \\ ORCID-ID: 0000-0002-6278-4600; Email: ynayak88@gmail.com \\ ${ }^{2}$ Research Professor, College of Management and Commerce, Srinivas University, \\ Mangalore, India \\ ORCID-ID: 0000-0003-2902-0163; Email: robinshinde@ gmail.com \\ ${ }^{3}$ Faculty, St Philomena College, Puttur, India \\ ORCID-ID: 0000-0001-9693-1990; Email: psmsuvarn@gmail.com
}

Area of the Paper: Business Management.

Type of the Paper: Research Case Study.

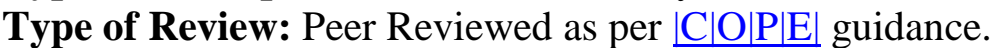

Indexed In: OpenAIRE.

DOI: https://doi.org/10.5281/zenodo.6285272

Google Scholar Citation: IJCSBE

\section{How to Cite this Paper:}

Nayak, Yashavantha G., Shinde, Robin M., \& Praveena (2022). Implication of Business Strategy in Indian Automobile Industry: A Case of Tata Motors. International Journal of Case Studies in Business, IT, and Education (IJCSBE), 6(1), 126-138. DOI: https://doi.org/10.5281/zenodo.6285272

International Journal of Case Studies in Business, IT and Education (IJCSBE)

A Refereed International Journal of Srinivas University, India.

Crossref DOI : $\underline{\text { https://doi.org/10.47992/IJCSBE.2581.6942.0155 }}$

(C) With Authors.

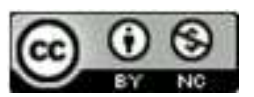

This work is licensed under a Creative Commons Attribution Non-Commercial 4.0 International License subject to proper citation to the publication source of the work.

Disclaimer: The scholarly papers as reviewed and published by the Srinivas Publications (S.P.), India are the views and opinions of their respective authors and are not the views or opinions of the S.P. The S.P. disclaims of any harm or loss caused due to the published content to any party. 


\title{
Implication of Business Strategy in Indian Automobile Industry: A Case of Tata Motors
}

\author{
Yashavantha G. Nayak ${ }^{1}$, Robin M. Shinde ${ }^{2}$ \& Praveena $^{3}$ \\ ${ }^{1}$ Research Scholar, College of Management and Commerce, Srinivas University, Mangalore, \\ India \\ ORCID-ID: 0000-0002-6278-4600; Email: ynayak88@ gmail.com \\ ${ }^{2}$ Research Professor, College of Management and Commerce, Srinivas University, \\ Mangalore, India \\ ORCID-ID: 0000-0003-2902-0163; Email: robinshinde@ gmail.com \\ ${ }^{3}$ Faculty, St Philomena College, Puttur, India \\ ORCID-ID: 0000-0001-9693-1990; Email: psmsuvarn@gmail.com
}

\begin{abstract}
Purpose: Strategic Analysis is a process of business organization which involves studying the business environment and its operations. For the effective decision making and smooth functioning of business organization, the strategic planning is an essential tool. An Indian multinational automobile manufacturing firm founded in 1945 by the Tata group under the name TELCO (Tata Engineering and Locomotive Company). Indian automaker Tata Motors is the biggest in the world. Since Tata Motors was founded, the company has been engaged in many charitable endeavours, including philanthropy. Strategic planning took a major role in the growth and profitability perspectives of this company. Tata Motors' acquisition of Jaguar and Land Rover is a unique example of a corporation making a strategic decision based on its internal strengths and external opportunities in order to succeed in a competitive market. Tata Motors sought to broaden the scope of its offering and the geographic scope of its market. A steady rise in the number of mergers in the Indian business has been observed over the past decade. Recently completed mergers and acquisitions are a good indicator of an industry's level of competitiveness, potentials, and capabilities. This research is undertaken to examine the firm's potential and capabilities by comparing its performance before and after mergers and acquisition.
\end{abstract}

Design/Methodology/Approach: When a company expanding its operations in the global level, some factors such as Economic, technological, customer-segment and international competitions will take a major role. The author of this paper has studied the growth of TATA Motors, both domestically and globally, in this study. For the purpose of the study secondary data is collected through various sources such as journals, research articles, newspaper articles and websites of Tata Motors and other ventures.

Findings/Result: The study highlights the critics of Tata Motors' acquisition desire factor out that the timing of the deal is affecting the worldwide economy. The call for business and passenger motors declined because of a slowdown with inside the home and international economy. The newly introduced Tata Nexon could be a game changer for the electric car market in the country due to India's large population and rising standard of living. Due to lack of innovation and major competitors in the market Tata Motors needs to be more innovative in its approach.

Originality/Value: This paper studies the effectiveness of mergers and acquisitions in terms of change in company's potentiality and capabilities.

Paper Type: Research Case study based on Company Strategic Analysis.

Keywords: Tata Motors Ltd, Indian automobile industry, Business strategy, Jaguar and Land Rover, Corporate social responsibility

\section{INTRODUCTION :}


Globalization and an atmosphere without borders make this phenomenon even more shocking. Consumers groups and political organizations are increasingly scrutinizing and putting pressure on businesses. It is the primary goal of CSR to create a social contract that will benefit all parties involved. There should be a long-term focus on welfare maximization as well as a short-term focus on meeting current expectations and requirements without jeo-pardising future generations' access to resources and opportunities. Organizational stakeholders have an interest in the firm and are influenced by the firm's actions, and they contribute to the firm's operations. Stakeholders, including shareholders, should be involved in the process of decision-making when it comes to developing CSR initiatives, and the firm should make a commitment to pay dividends and enhance share value to guarantee that their contributions continue. CSR in family businesses is one of the unexplored areas of CSR research in India, a highly competitive market. There are a lot of businesses out there today, but only a small percentage of them are investing in education through CSR efforts. The Tata Group is one of India's most reputable corporations. The Tata family has been running the Tata Group since its inception. Tata Group's history may be traced back to a tiny commercial firm that was founded in 1868. There is now a well-established corporation that has a vast distribution network and wholesale activities in place since the company was founded. In the Zoroastrian community of Parsis, he was the sole child of Nusserwanji Tata. With his father's bank, he founded a trade enterprise, while working as a clerk. Founded Tata \& Sons with Ratanji Dadabhoy and his oldest son Rattan Tata in 1887, this was the beginning of the company's principal operation. Entrepreneurship, cooperation, and family ties all played a significant role in this start-up, which could be regarded as a family business. The Tata group founded Tata Motors in 1945.

Competition for Tata Motors' passenger, luxury, and commercial cars is fierce both domestically and internationally. In their native nation, they are exposed to a wide range of both opportunities and risks. It is imperative for Tata Motors to take preventative and anticipatory action against these dangers as well as to identify and exploit the many opportunities. A lack of new entrants in the car business is due to the high entry barriers, yet since substitute goods are readily available, the auto industry faces particularly harsh competition. Even though Tata Motors faces stiff competition and a tarnished reputation, the company has a number of organizational assets that can help it distinguish apart. Tata must keep Jaguar and Land Rover apart from the rest of its activities in order to safeguard the prestigious brand image of JLR. In addition, Tata's relationship with the Tata Group can be leveraged to benefit both companies financially. Finally, Tata Motors must take advantage of both India's young population and the lack of disposable wealth in third-world countries by introducing a new Nano model.

\subsection{Separation of JLR and Tata Motors:}

Tata Motors' acquisition of Jaguar and Land Rover (JLR) was critical to the company's success in the premium automotive market. As a luxury car manufacturer, Tata Motors relies heavily on Jaguar Land Rover (JLR) for revenue and profit margins. JLR's prestige, reputation, market share, and more distinguish it from Tata Motors. I believe Jaguar Land Rover (JLR) should be kept as far apart from Tata Motors as possible in order to protect their brand. JLR's reputation is expected to suffer as a result of their association with Tata Motors, which some may see as a good thing because it will help Tata improve its image. As opposed to relying on JLR to assist improve the image of another brand, Tata should focus on repairing its own reputation. No one should risk harming Tata's reputation in the hopes of improving Tata's already-tarnished reputation. Ultimately, I believe Tata Motors should maintain JLR's marketing, distribution, and the entire value chain distinct from Tata's primary company.

\subsection{Evolution of Tata Motors Commercial Vehicle (CV) Business:}

In 1954, Mercedes Benz and Tata Motors collaborated to produce medium commercial cars. Over time, the import content was gradually reduced until it was nearly nonexistent by 1969 , the year the collaboration came to an end. When Tata Motors began designing its own automobiles, the company had already gained the necessary expertise. Heavy-duty commercial vehicles were added to the company's product line in the 1970s. It became the most popular M\&HCV in India. Tata Motors has expanded into numerous new commercial vehicle segments throughout the years, as well as creating entirely new segments with products like the Tata Ace, Zip, Magic, and Iris. As a result, it has become the market leader in nearly all of the commercial vehicle areas in which it operates. 


\subsection{Tata Motors Commercial Vehicle Business:}

\subsubsection{Medium \& Heavy Commercial Vehicles (M\&HCV):}

The domestic CV industry's buoyancy has waned since 2009-10 and 2010-11, when it experienced volume growth of more than $30 \%$. In the last three years, the M\&HCV industry has been hit particularly hard by a slowdown in industrial activity, a lack of investment enthusiasm, and the impact of a major increase in fleet capacity in the heavy-duty trucking market. Higher-tonnage trucks including tippers, tractor trailers, and multi-axle vehicles (MAVs) have seen their demand decline the most in the M\&HCV industry. In FY' 2012-13, M\&HCV volumes fell by 29 percent year-on-year as a result of these issues. The current phase is marked by lower cargo volumes, increased competitiveness due to surplus capacity (M\&HCV sales doubled from the lows of FY' 2008-09, bringing down the average age of M\&HCV population to a 10-year low), and growing operating expenses, especially in light of the recent fuel price hikes. The M\&HCV industry's competitive landscape has been evolving at a rapid pace. Before 2005, the industry only had a few large participants, most of which were domestically based. Today, major global players have entered the fray. There are currently more than ten "global and Indian" OEMs competing for market share in today's business. With its Indian subsidiary Daimler India Commercial Vehicle, Diamler has become the newest player in this market (DICV). It is expected to compete with Tata Motors in practically all segments, just as Tata Motors. Across the world's largest $\mathrm{CV}$ markets, the market leaders hold barely a 20 to 25 percent market share in most of the competition. In this respect, Tata Motors holds a unique position within the M\&HCV industry. Currently, it holds a $62 \%$ market share in this particular sector. The objective for Tata Motors is to keep the same and improve it further, therefore reversing a global trend in the Indian market.

\section{LITERATURE REVIEW :}

Hedieh Divsalar et al (2016): India is the world's second-most populous country, and its economy is seeing rapid expansion, indicating that a wide range of industrial products are in great demand. As of the middle of the 1990s, the country's automobile industry grew at a breakneck pace. Maruti and Honda Siel have recently made significant investments in the area, which are likely to have a positive impact. The sector is likely to benefit from Tata's proposed investment in the manufacturing of a low-cost automobile. All categories of the commercial vehicle market, including heavy and medium commercial vehicles, light commercial vehicles and pick-up trucks, as well as the core segments of the passenger vehicle market (compact and midsize cars and utility vehicles) are represented by Tata Motors. The Tata Motors Presence in new countries such as the UK, Libya, Egypt and Tunisia will also be expanded. Brazil, Colombia, Peru, Mexico, Yemen, Angola, Malaysia, Indonesia, and Australia are some of the countries in the region [1].

M. Sekara et al (2014): During the course of the investigation, the company's net worth began to rise. Because to debt repayments and debt exchanging, the amount of debt capital has dropped from 2010 to 2011. Over time, the company's WACC (weighted average cost of capital) changed. Because of massive losses and a decrease in net worth in the financial year 2003-04, it is extremely high. A rise in debt capital has resulted as a result. The company's WACC began to decline in 2004-05 as a result of the company's shift toward cost-effectiveness. There is a very low amount of debt in the company's capital structure based on the company's debt ratio and debt equity ratio. As the danger of the equity holder's increased with an increase in loans, so did the owner's fund and confidence. The company's fixed costs of funding have exceeded its return on assets, lowering the company's ROE, ROI, EPS, and other financial metrics. The ROE, the value of debt and equity, and the firm's value are all positively connected with the firm's value [2].

Seema Laddha (2016): Critics of Tata Motors' acquisition choice point out that the timing of the deal is affecting the global economy. The demand for commercial and passenger vehicles declined after purchase due to a slowdown in the domestic and global economy. Prior to the acquisition of Tata Motors, Tata Motors mostly generated its revenue from the sale of commercial vehicles. The corporation will be able to expand its luxury passenger vehicle brand with this acquisition. To acquire Tata, the economic downturn provided a chance for Tata Motors. For half of what Ford spent for these two iconic brands in 2005, Ford was ready to sell these two legendary brands. Tata Motors has an opportunity to become a global company and enter the luxury passenger vehicle market, which may not have been achievable in the absence of Ford's distress sale. It is possible for Tata Motors to make such 
a strategic move because of their management expertise, extensive experience in a major market like India, strong brand recognition, and solid financial standing [3].

Jaspreet Singh et al (2018): According to the study, Tata Motors has been conducting outstanding work in a variety of industries since 2013. However, the firm has been doing these activities prior to the government's official announcement in 2013. The investigation discovered the variety of work performed by the company and the positive impact it has on the community. The company has done a variety of various kinds of work, which has benefited people in a variety of ways in different parts of the country. In general, Tata Motors' CSR programmes focus on labour, the environment, and other economic issues. Tata Motors' practise in India is compared to the CSR framework, and the comparative table demonstrates that practically every variable is addressed in the sample firms. It has been shown that a vast number of people have benefited from this research. Tata Motors has invested a lot of money in these areas, and future research can be done by evaluating this data [4].

Siddalingya et al (2018): Consolidation in Indian industry has accelerated as a result of economic liberalization and globalization efforts launched since 1991 by the Indian government. A steady rise in the number of mergers and acquisitions in the Indian business has been observed over the past decade. Recently completed mergers and acquisitions are a good indicator of an industry's level of competitiveness, potentials, and capabilities. It is the goal of this research to examine the firm's potential and capabilities by comparing its performance before and after merger and acquisitions. This study relies primarily on data that was obtained from other sources. Analytical methods used to measure financial performance include ratio analysis, standard deviation and " $t$ " test and "paired $t$ " test. The financial performance of the selected companies prior to and following the mergers and acquisitions has not been significantly affected by the mergers and acquisitions [5].

Shamim Akhtar (2013): A lot of factors may have contributed to Tata Nano's underwhelming debut on the market. The Singur crisis and the accompanying uncertainty over the economic climate were some of the unanticipated and inevitable difficulties they encountered at first. It's fair to say, though, that some fundamental blunders were made in the early stages of the company's marketing. We didn't grasp and address the real psychology of our target audience. Tata Motors has rethought its whole approach with the Nano after making mistakes in the past. It all started with a new approach to distribution. Smaller towns and rural India received the most attention. Aiming for tier-3 and tier-4 municipalities, they planned to open more than 300 dealerships [6].

Vineet Singh (2015): Tata Motors and Maruti Suzuki maintained a debt equity ratio of 0.63:1 and $0.02: 1$ over the study period of $2010-11$ to $2014-15$, which is lower than the normal ratio of $2: 1$, according to the above analysis and interpretation. From a long term perspective, a debt equity ratio of less than 2:1 is considered desirable, whereas a debt equity ratio of more than 2:1 is considered dangerous. Debt equity ratio is a measure of the proportion of long-term borrowings in comparison to shareholder's cash that are used to fund the company. Long-term borrowings that are more than twice the shareholders' cash indicate that a company relies more heavily on long-term borrowings than it did in the past. Long-term borrowings have a negative effect on a company's long-term solvency, while short-term borrowings have a positive effect on a company's long-term solvency. If a company's obligations are equal to or less than its equity, this indicates that it will have no trouble repaying its debts in the long term; however, if its debts are greater than its equity, this indicates that it may have difficulty repaying its debts in the long term [7].

Prashant Salwan (2017): A company's growth and internationalization are intertwined. Economic, technological, customer-segment, level of competition, and many other factors all have a role in the risk of expanding internationally. TATA Motors' domestic and international expansion has been explored in this study by the author. In this study, strategy formulation procedures were employed to cover a time period from the recession of 1999 to the current day. Strategy and lessons learned were mapped out in an attempt to make sense of the process. From international business strategies to product strategies and market selection, the sessions covered a wide range of topics. Analysis of growth has made use of the theory of firm framework [8].

Abhishek Kumar et al (2020): Because of its parent business Tata Group, Tata Motors Limited is a strong company that has been bolstered by the numerous acquisitions and mergers. Investing in research and development shows that the organization has a well-trained personnel. The company's decision to create an electric version of Nexon is a logical step in the right direction at a time when the globe is concerned about decreasing its carbon footprint. The massive population of India and the rising wealth 
level of the country could prove to be a game changer for Tata Nexon, the company's recently unveiled electric vehicle. In addition to the company's issues, it also has its advantages. The electric car industry faces a big issue due to a lack of innovation. Because major competitors like General Motors, Mitsubishi Motors, Ford, and Fiat have been experimenting with new ideas recently, Tata needs to do the same. The expensive cost of electric vehicles could be a problem for the corporation, too. In spite of the great market potential for electric vehicles, India is a lower-middle-income country, and so, most people cannot afford to own one [9].

Bruche et al (2010): The case study of TML's resource and capacity generation process in the passenger car market provides a lot of valuable insights and conclusions. Although TML hasn't yet caught up to the global market giants, it has developed from an initial entry into a medium-sized passenger car company that has become a force to be reckoned with14 in a short period of time. First and foremost, Tata's and TML's enormous antecedent human, technological, and reputational resources - beyond the financial endowment necessary for such a move - were exploited in TML's resource creation strategy at the time of its entry into the new business segment. Another factor that helped to speed up the process of catching up and increasing the group's resources and capabilities was the creation of a new dynamic capability at the group level, which reduced the traditional 'time compression diseconomies' that are inherent in resource accumulation processes (Dierickx and Cool 1989). Ratan Tata's strong leadership personality and a protracted process of capability-enhancing transformational changes at the group level have resulted in this dynamic capability [10].

\section{METHODOLOGY :}

The data required for this is collected through various secondary sources such as journals, published papers, archived newspaper articles and company websites of Tata Motors and other ventures.

\section{CORE VALUES OF TATA MOTORS :}

The Tata Group has always been committed to its core values. Tata's business continues to be guided by these ideals

1. Morality: We need to behavior our commercial enterprise fairly, with honesty and transparency. Everything we do ought to stand the take a look at of public scrutiny.

2. Understanding: We have to be caring, display respect, compassion and humanity for our colleagues and clients across the world, and constantly paintings for the advantage of the groups we serve.

3. Outstanding: We shall continuously try to acquire the very best viable requirements in our daily paintings and within side the first-class of the products and offerings we provide.

4. Integration: We ought to paintings cohesively with our colleagues throughout the institution and with our clients and companions across the world, constructing robust relationships primarily based totally on tolerance, expertise and mutual cooperation.

5. Responsibility: Responsibility, sensitivity, and subject for the people, locations where we work and the surroundings wherein, we function are all crucial to our success.

\section{SWOT ANALYSIS OF TATA MOTORS :}

Ford Motor Company's SWOT analysis has been discussed previously, so we'll now examine TATA Motors' framework. TATA Motors, as previously stated, places a high priority on identifying and capitalizing on opportunities. In the case of the Tata Nano announcement, they made the model and opened bookings considerably earlier than they had the manufacturing capacity to match demand, ignoring the fact that they would wind up with a massive backlog of client orders.

Businesses need strategic planning, and SWOT analyses play a key role in the process of strategizing. It can be used in any setting, from a team to an entire organization. With the help of a SWOT analysis, the impact of external and internal demand and influences on an organization's performance may be determined. In some cases, collecting data for stakeholder and competitor analysis, as well as a study of specific organizational challenges, scanning and scenario analysis of the environment, might be useful. As part of the SWOT analysis, major factors on behaviour and success in an organization are also taken into consideration.

SWOT stand for-

"S-Strengths" 


\author{
"W-Weakness" \\ "O-Opportunities" \\ "T-Threats"
}

\title{
5.1 Strengths:
}

To far, Tata Motors has been the major market taker in the automobile sector and has a significant market share. Tata Motors is a great place to work, with a high level of productivity from its manufacturing facilities. In India, their brand is highly regarded. The Tata Nano, the world's cheapest and most fuel-efficient car, is their greatest asset. It provides Tata Motors with a distinct advantage over its competitors. Tata benefits from this by being able to grab a large market and clients. There are 3500 Tata dealership, sales, and service touch locations. Developments have been made in the Tata Acc and Taj Magic areas of the company, among others. These goods have not yet been replaced on the market. In addition, the company has a high level of corporate responsibility. In addition, they donate a portion of their profits to charity by increasing their stock value. This demonstrates that they want to better the community as a whole. Tata Motors has made a point of acquiring brands from other countries in order to broaden its worldwide reach. There is a lot of research and development going on at Tata Motors.

\subsection{Weakness:}

Tata Motors' primary shortcoming is the inability to generate a profit from its equity investments. When compared to its rivals, their vehicle does not sustain the same high level of safety regulations. In the domestic market, Tata Motors' product sales fall short of expectations. India sells fewer than 1 million cars a year. If consumers don't want to buy a car, how will the corporation be able to make money? As compared to its rivals, technological advancement is not as advanced as it should be. Jaguar and Land Rover are owned by Tata, yet Tata has yet to gain a foothold in the luxury automobile market. Tata's most recent idea is called A few issues remain to be worked out, including as the emissions of pollutants and greenhouse gases from the generation of electricity used to compress air. This is a flaw in the system as a whole. In addition, the One CAT can only travel 56 miles at 62 miles per hour in an urban cycle. In order to attract more buyers, Tata Motors will have to overcome this vulnerability and the emissions issue.

\subsection{Opportunities:}

Because this car is affordable in third world countries, Tata Motors can expand into such markets. They can easily take the market because this low-cost car is fuel efficient and affordable. Exports to other countries are an option for them, as well. In order for Tata Motors to succeed, it needs to focus on premium vehicles. Increased safety measures in vehicles can help Tata Motors achieve more customer satisfaction. Because of their collaborative partnerships with other countries, they have easy access to new markets.

In 2006, China was the world's second-largest market for automobiles, with an estimated annual sales value of $\$ 8$ million. According to government estimates, China would need 20 million new cars by 2020. The introduction of Tata Motors' cheapest automobile to the market will result in a significant increase in demand for the vehicle in China. Tata Motors sees an uptick in revenue as a result of this. Tata Motors and Ford Motor Company signed an agreement in 2008 to form a joint venture. Tata Motors will have a wonderful opportunity to gain experience and technology for the production and marketing of luxury vehicles as a result of this. Their entry into the established markets of Japan, Europe, and the United States will be facilitated by this acquisition. Tata Motors' ability to continue to grow and prosper in both developing and developed markets will greatly benefit from the exchange of expertise between the two firms.

\subsection{Threats:}

Tata Motors will continue to enjoy a competitive advantage over its rivals as long as its competitors can create a low-cost production technique.

The competition has begun for them already if there is a market competition. Actually, a four-wheeled vehicle has been manufactured by Pakistan's Transmission Motor Company that costs just over \$2,000. So cheap that they have started selling this car to countries like Sudan, Qatar and Chile. It's just the beginning of a new wave of low-priced car makers. Another difficulty for Tata Motors is the rising cost 
of raw materials like steel, aluminum, and plastic. Sales of autos could be hampered by a lack of safety requirements.

\subsection{TATA Motors Strengths:}

- "Excellent brand equity and strengths in Indian Market"

- "Legacy and Dignity of Tata brand heritage which is almost as old as Ford Motor Company"

- "Sound global recognition in light trucks and buses"

- "Sound fundamentals in turbo diesel engines that they developed in joint venture with Cummins"

- "Sound presence in Asian Markets"

- "Ownership of the heritage of British motor brands - Land Rover and Jaguar"

- "Strategic tie up with Mercedes Benz which is one of the hottest cars in premium car market segment in India"

- "World class quality accreditations (ISO 9001, ISO 20000, ISO 14001)"

- "Excellent cost management framework (Ariba Spend Management)"

- "Excellent Supply Chain Management using the SAP framework"

- "Experienced, high quality, productive and low cost work force"

- "Ownership of some of the largest automobile manufacturing plants of the world"

- "Diversification strengths due to other large businesses of Tata Group"

- "Excellent financial strengths - close to \$10 Billion of annual revenues"

\section{ENTERPRISE PROCESS MODEL (EPM) - PROCESS MANAGEMENT AT TATA MOTORS:}

Analysts had all but written off TATA Motors' future after the company suffered a 500 crore loss in 2000-01. TML, on the other hand, was determined to get back on its feet, and thus began the process of significant self-reflection and improvement. For the significant loss, three main factors were identified: lack of emphasis on customers (a), process management (b), and absence of innovative items and variants (c). Process management was TML's primary focus while deciding on the three aspects. Because of this, the Tata Business Excellence Model (TBEM, based on the Malcolm Baldrige National Quality Award Process) was developed by TATA Motors, which began to use the American Productivity and Quality Center's (APQC) 13 processes and sub-processes. As a result, the 'impact' of individual employees was greatly reduced. When the procedures were documented, there was a great deal of clarity in terms of who owned what and what they were responsible for as well as what they were responsible for delivering, what they were responsible for delivering as well as what they were responsible for delivering. The Enterprise Process Model has been depicted in the figure below.

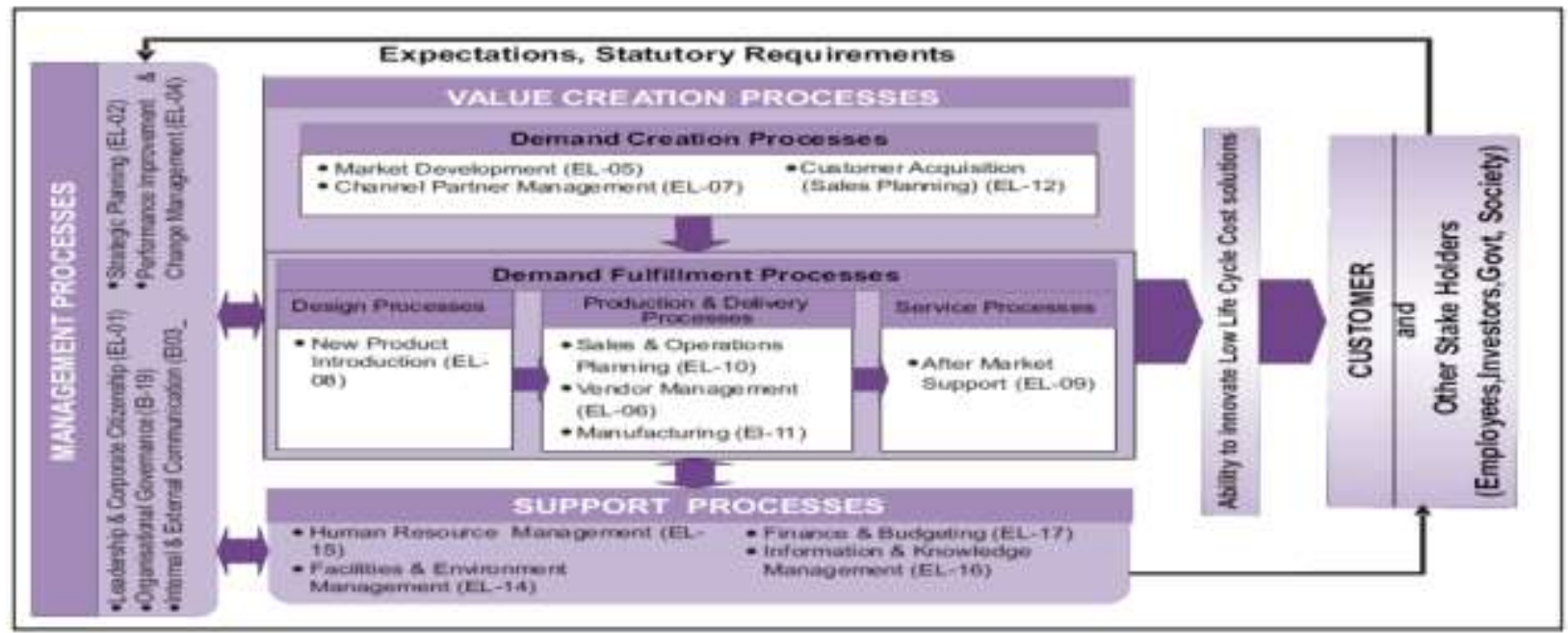

Fig. 1: Enterprise Process Model [11] 


\section{MANUFACTURING :}

Manufacturing processes are the primary focus of quality in an automobile sector. We would have to assemble and activate roughly fifteen thousand components and accessories while making a car. Developing manufacturing processes and technology in-house is a priority for TATA Motors. Unless there are a lot of other car companies doing the same thing, the company's goal is not to mindlessly accept any new technology that succeeds. It is a firm believer in cutting-edge innovation. TATA Motors follows a diversification strategy by creating new products and entering new markets to sell them, as shown by the product market matrix (which includes product creation, market development, market penetration, and diversification).

\section{THE CONTRIBUTION OF 'GROUP AFFILIATION ADVANTAGE' TO TATA MOTORS' CATCH-UP :}

A major impact on the Indian passenger car market was felt when TML was still producing CVs under India's New Economic Policy. As part of the acquisition of Jaguar Land Rover (JLR), TML has transformed itself into the world's second-largest automaker, creating a new product line (the Indica), expanding its capabilities (the Nano), and becoming a worldwide automaker in a single "leap." As an independent automaker, would this process of rapid capability expansion have been conceivable, or would it have had to be funded by the capital market? TML's connection with the Tata Group has made a substantial contribution to the company's capability creation and internationalization process, and the following analysis sheds some light on these issues. First, we'll take a look at six 'affiliation benefits' that can be found in the available resources and experts' discussions.

\section{INDIA BASED MANUFACTURING :}

Over time, Tata Motors Limited has gained a significant market share thanks to mergers and acquisitions. Increase the development of new products and expand into new markets in order to gain more market share in the domestic electric vehicle industry for the company. As part of their CSR efforts, Tata Motors should promote electric vehicles. To stay ahead of the competition, a company must never rest on its laurels in terms of innovation. A range of mass marketing and environmental education programmes should be used to persuade people to use electric-powered vehicles. Establishing strong foundations of support, setting legal frameworks, encouraging innovation and new business models as well as incentives and subsidies are all steps that Indians may do to create a healthy environment for electric vehicles.

\section{FACTORS WHICH INFLUENCES CAPITAL STRUCTURE :}

\subsection{Business Risk:}

Excluding debt, business risk is the basic risk of the company's operations. The greater the business risk, the lower the optimal debt ratio.

\subsection{Company's Tax Exposure:}

Tax deductions are available for debt repayments. Due to the tax deductibility of the loan payments, a company's tax rate can be reduced by using debt to finance a project, making it more desirable to do so. As a result, debt serves as a more cost-effective source of capital. The debenture holders or creditors, on the other hand, cannot participate in the company's gains, allowing it to retain a large portion of its earnings during periods of prosperity. Additionally, the current equity shareholders will reap the rewards.

\subsection{Financial Flexibility:}

This is basically the company's ability to raise money in hard times. It should come as no surprise that businesses that are experiencing high sales and profits have little trouble raising cash. Even in the best of circumstances, raising financing isn't as difficult because of the company's solid cash flow. When things are good, companies should be careful not to overextend their financial resources by seeking cash. The more financial flexibility a corporation has, the lower its debt level must be. Too much debt might make it difficult for companies to raise financing through debt. 
10.4 Management Style:

A wide variety of management styles exist, from aggressive to cautious. The less risk-averse a company's management is, the less likely it is to resort to borrowing money to boost earnings. Debt may be used by an ambitious management to fast grow the company and increase the company's profitability per share (EPS).

\subsection{Growth Rate:}

When a company is in the early stages of its lifecycle, it is common for it to take out loans in order to expand. There is a problem with this strategy because growth companies' revenues tend to be volatile and unproven. Thus, a heavy debt load should be avoided at all costs. Due to their proven earnings, mature and reliable companies often require less debt to fund expansion. For projects that arise, these companies create financial flow that can be employed.

\subsection{Market Conditions:}

A company's capital structure can be significantly affected by market conditions. Let's say a business wants to take out a loan to build a new factory. A company's borrowing costs may be too high if the market is experiencing difficulties, which means investors are restricting the amount of cash available to enterprises due to general market uncertainty. In this case, a corporation may want to wait until the market has stabilized before attempting to get funding for the plant.

\subsection{Market Analysis:}

The Indian vehicle market appears to be developing, propelled by the country's rapid economic expansion. India's two decades of strong economic growth have produced a large middle class with a disposable income ranging from Rs. 200,000 to Rs. 1 million, which is documented in the case study. In 2005 , only $5 \%$ of the Indian population was middle class, and this proportion is anticipated to climb to $19 \%$ in 2015 and $41 \%$ in 2025 . Spending on transportation is predicted to rise in India as incomes rise. Transportation expenses accounted for $17 \%$ of household income in 2005, and this percentage is predicted to climb to $19 \%$ in 2015 and $20 \%$ in 2025. As incomes rise, so should the number of people buying cars. Although the middle class has grown in size and money, most customers are still looking to buy the cheapest things they can get their hands on. The Tata Nano was conceived as a four-wheeled vehicle that could be afforded by a significant segment of India's middle class. As earnings rise and the middle class expands, the Nano's market potential in India is likely to grow.

\section{CONCLUSION :}

As the second most populous country in the world, India has a strong growth rate in its economy, which means that there is a large need for products in various industrial areas. As of the middle of the 1990s, the country's automobile industry grew at a breakneck pace. Maruti and Honda Siel have recently made significant investments in the area, which are likely to have a positive impact. The sector is likely to benefit from Tata's proposed investment in the manufacturing of a low-cost automobile. Critics of Tata Motors' acquisition choice point out that the timing of the deal is affecting the global economy. The demand for commercial and passenger vehicles declined after purchase due to a slowdown in the domestic and global economy. Before the takeover of Tata Motors, Tata Motors' primary source of revenue was commercial vehicles. In the luxury passenger vehicle market, this acquisition will help the corporation grow its brand. To acquire Tata, the economic downturn provided a chance for Tata Motors. The failure of Tata Nano to make a significant impact on the market might be due to a variety of factors. As a result of the Singur crisis and following economic instability, they experienced a number of unanticipated and unavoidable difficulties at first. Because of several acquisitions and mergers, Tata Motors Limited is a powerful corporation that has been backed by its parent organization, the Tata Group. Investing in research and development shows that the organization has well-trained personnel. By producing an all-electric version of the Nexon, the corporation is taking a step in the right way at a time when environmental concerns are becoming more prominent. Because of India's large population and rising standard of living, the newly introduced Tata Nexon could be a game changer for the electric car market in the country. However, the corporation faces its fair share of difficulties. The electric car industry faces a big issue due to a lack of innovation. So far, major competitors such as Ford and Fiat have been quite original in their approach. Tata therefore needs to be more innovative in the approach. 


\section{REFERENCES :}

[1] Divsalar, H. (2016). Export Marketing Strategy of Automobile Industry in India: A Case Study Of Tata Motors Ltd. Advances in Bioresearch, 7(2), 1-20.

Google scholar $X^{7}$

[2] Sekar, M., Gowri, M. M., \& Ramya, M. G. (2014). A study on capital structure and leverage of Tata Motors Limited: Its role and future prospects. Procedia Economics and Finance, 11(1), 445-458.

Google scholar $X^{\top}$

[3] LADDHA, S. (2016). Acquisition Strategy: Analysis of Tata Motor's Jaguar Land Roar. International Journal of Management \& Business Studies, Maharashtra, India, 6(1), 17-21.

Google scholar $x^{\top}$

[4] Srivastava, A. K., Negi, G., Mishra, V., \& Pandey, S. (2012). Corporate social responsibility: A case study of TATA Group. IOSR Journal of Business and Management, 3(5), 17-27.

Google scholar $X^{\top}$

[5] Siddalingya. (2018). The Performance Of Merged Tata Group Companies In India - A Case Study of Tata Motors Company Limited. International Research Journal of Management and Commerce, 5(2), 223-237.

Google scholar $x^{7}$

[6] Akhtar, S. (2013). Behind the Nano mistakes: A case study on consumer psychology. Srusti Management Review, 6(1), 57-67.

Google scholar $x^{\top}$

[7] Singh, V. (2015). Long Term Solvency Analysis: A Case Study of Tata Motors and Maruti Suzuki. International Journal of Management, 4(9), 1-12.

Google scholar ${ }^{7}$

[8] Salwan, P. (2011). Growth \& internationalization: the case of TATA motors. Indian Journal of Industrial Relations, 4(2), 41-19.

Google scholar 7

[9] Kumar, A., \& Hallur, G. G. (2020). Driving The Electric Vehicle Revolution in India: Case Study of Tata Nexon. PalArch's Journal of Archaeology of Egypt/Egyptology, 17(6), 4273-4287.

Google scholar $X^{\nearrow}$

[10] Bruche, G. (2010). Tata Motor's transformational resource acquisition path: A case study of latecomer catch-up in a business group context. Econdstor, 17(4), 1-15.

Google scholar $x^{7}$

[11] Luthra, S., Kumar, V., Kumar, S., \& Haleem, A. (2011). Barriers to implement green supply chain management in automobile industry using interpretive structural modeling technique: An Indian perspective. Journal of Industrial Engineering and Management (JIEM), 4(2), 231-257.

Google scholar $X^{7}$

[12] Mitra, R. (2011). Framing the corporate responsibility-reputation linkage: The case of Tata Motors in India. Public Relations Review, 37(4), 392-398.

Google scholar $x^{\top}$

[13] Chandra, N. K. (2008). Tata motors in Singur: a step towards industrialization or pauperisation?. Economic and Political Weekly, 11(1), 36-51.

Google scholar $x^{\top}$

[14] Becker-Ritterspach, F., \& Bruche, G. (2012). Capability creation and internationalization with business group embeddedness-the case of Tata Motors in passenger cars. European Management Journal, 30(3), 232-247.

Google scholar 7 
[15] Sekar, M., Gowri, M. M., \& Ramya, M. G. (2014). A study on capital structure and leverage of Tata Motors Limited: Its role and future prospects. Procedia Economics and Finance, 11(1), 445458.

Google scholar $x^{\nearrow}$

[16] Salwan, P. (2011). Growth \& internationalization: the case of TATA motors. Indian Journal of Industrial Relations, 1(1), 1-19.

Google scholar $x^{\prime}$

[17] Palepu, K., Anand, B. N., \& Tahilyani, R. (2011). Tata Nano-The people's car. Harvard Business School Strategy Unit Case, 1(4), 137-150.

Google scholar $\chi^{\prime}$

[18] Rao, V. R., \& Kumar, R. V. (2012). Customer satisfaction towards tata motors-A study on passenger cars in Warangal district of Andhrapradesh. South Asian Journal of Marketing \& Management Research, 2(4), 127-150.

Google scholar $\nearrow^{\top}$

[19] Chaklader, B., \& Roy, D. (2010). Sustainable development using the sustainability balanced score card: the case of Tata Motors, India. International journal of sustainable strategic management, 2(2), 155-167.

Google scholar $x^{2}$

[20] Kumar, S., \& Bhatia, G. K. (2014). Financial performance of Indian automobile companies after liberalization: A comparative study of Maruti Suzuki and Tata Motors. International Journal of Advanced Research in Management and Social Sciences, 3(9), 186-195.

Google scholar $X^{\top}$

[21] CRAINER, S. (2010). The tata way. Business Strategy Review, 21(2), 14-19.

Google scholar $x^{\top}$

[22] Sureshkumar, V. (2019). Impact of capital structure on profitability of automobile companies in India (with special reference to Tata Motors Ltd. And Mahindra \& Mahindra Ltd.). A Journal of Composition Theory, 5(1), 120-130.

Google scholar $\chi^{7}$

[23] Kaur, R. (2012). Performance evaluation of automobile company: a case study of Tata motors. ACADEMICIA: An International Multidisciplinary Research Journal, 2(1), 123-140.

Google scholar $X^{\top}$

[24] Srivastava, A. K., Negi, G., Mishra, V., \& Pandey, S. (2012). Corporate social responsibility: A case study of TATA Group. IOSR Journal of Business and Management, 3(5), 17-27.

Google scholar $\not^{\top}$

[25] D'costa, A. P. (1995). The restructuring of the Indian automobile industry: Indian state and Japanese capital. World Development, 23(3), 485-502.

Google scholar $\chi^{7}$

[26] Gopal, P. R. C., \& Thakkar, J. (2016). Sustainable supply chain practices: an empirical investigation on Indian automobile industry. Production Planning \& Control, 27(1), 49-64.

Google scholar $X^{\nearrow}$

[27] Sarangi, P. K., Bano, S., \& Pant, M. (2014). Future trend in Indian automobile industry: A statistical approach. Apeejay-Journal of Management Sciences and Technology, 1(2), 28-32.

Google scholar $x^{7}$

[28] Kumar, R., Lamba, K., \& Raman, A. (2021). Role of zero emission vehicles in sustainable transformation of the Indian automobile industry. Research in Transportation Economics, 90(1), 101064.

Google scholar $X^{7}$ 
[29] Shalender, K., \& Yadav, R. K. (2019). Strategic flexibility, manager personality, and firm performance: The case of Indian Automobile Industry. Global Journal of Flexible Systems Management, 20(1), 77-90.

Google scholar $x^{7}$

[30] Chowdhury, S. G., \& Chatterjee, S. (2020). Determinants of Indian Automobile Industry Growth. Eurasian Journal of Business and Economics, 13(26), 65-91.

Google scholar $\chi^{\top}$

$* * * * * * * * * * *$ 